\title{
Foreign Direct Investment Spillovers and the Ghanaian Local Financial Environment
}

\author{
Festus Ebo Turkson', Agyapomaa Gyeke-Dako², Emmanuel Bentum Amissah ${ }^{3}$ \\ ${ }^{1}$ Department of Economics, School of Social Science, College of Humanities, University of Ghana, Accra, Ghana \\ ${ }^{2}$ Department of Finance, Business School, College of Humanities, University of Ghana, Accra, Ghana \\ ${ }^{3}$ Division of Economics, Nottingham Business School, College of Business Law \& Social Sciences, Nottingham \\ Trent University, Nottingham, UK \\ Email: feturkson@yahoo.com, eturkson@ug.edu.gh, afuagyekedako@yahoo.co.uk, agyeke-dako@ug.edu.gh, \\ bentum2000@yahoo.com, emmanuel.amissah@ntu.ac.uk
}

Received 11 September 2015; accepted 24 October 2015; published 27 October 2015

Copyright (C) 2015 by authors and Scientific Research Publishing Inc.

This work is licensed under the Creative Commons Attribution International License (CC BY).

http://creativecommons.org/licenses/by/4.0/

(c) (i) Open Access

\begin{abstract}
Using the bound cointegration test, we examine how Foreign Direct Investment (FDI) influences Ghana's growth through the financial environment. We use data from different sources including the World Development Indicators (WDI) of the World Bank, covering the period 1977-2010 to address this. Our key results are interesting. Specifically, our results show that, both in the short run and in the long run, FDI will have a better influence on growth in a sound financial environment. However, whiles the capital market is important to propel FDI's influence on Ghana's growth in the long-run; in the short run, developing the banking sector alone is not sufficient to achieve growth. Banking sector development needs FDI to influence growth. Our results justify enormous efforts made by Ghana to attract FDI and further suggest that the continuation of this policy will be beneficial to the economy given the relative progress made with regards to banking system and capital market development over the past two decades.
\end{abstract}

\section{Keywords}

Foreign Direct Investment, Spillovers, Financial Environment, Banking System, Capital Markets

\section{Introduction}

Conventional wisdom concludes that FDI promotes growth through technological spillovers and provides scarce resources to host countries' firms. This is the reason why most countries have given incentives to attract FDI. In recent years, countries in Sub-Saharan Africa (SSA) particularly Ghana have seen notable increases in net in- 
flow of FDI [1]. Interestingly, almost all of those SSA countries that have been a popular destination for FDI have provided enormous incentives to attract FDI's. In Ghana, for instance, the Free Zones Act gives foreign firms which export at least $70 \%$ of their products tax holidays initially and lower taxes after the grace period. In addition, under the Free Zones Act, the Ghana Free Zones board has established a freezone enclave where infrastructure is fully developed for firms to cite. The general belief is that, because FDIs are able to provide scarce capital and generate technological spillovers for domestic firms, providing these incentives to attract them can benefit the host country.

Although the provision of such incentives is in the right direction, the many benefits expected from FDI still remain elusive for most SSA countries including Ghana. In some cases, the impact of FDI on growth has been negative. The rationale is that the presence of FDI instead of providing support (through technology spillovers and innovation) for the local firms may capture the market shares of the local firms or even borrow from the local financial market and crowd local firms out. This is expected since foreign firms will generally have a longer track record, and they stand in a better position than the local firms to get access to the domestic funds. This is supported by findings from Frimpong and Oteng-Abayie [2], Asiedu [3] and Waldkirch and Ofosu [4]. Thus, though FDI can generally be seen to promote growth, contrary to this view, these studies among others have found that FDIs are always not beneficial to host countries ${ }^{1}$. From this, it is obvious based on empirical evidence that the growth-enhancing impact of FDI remains inconclusive.

Recent strand of studies have shown that the domestic environment in countries can facilitate the attraction as well as provide the necessary platform for the realisation of the benefit of FDI [6] [7]. Among the factors within the domestic environment that facilitate the attraction of FDI, is a proper functioning and well-developed financial sector/market. Very few studies [6] [8], however, have examined the role of financial markets on the effective relationship between FDI and growth.

This study will examine how the proper functioning of the financial environment can help facilitate the role FDIs played in the growth of the Ghanaian economy. We also extend this work by classifying the financial environment into its constituents to identify the more effective channel of the financial environment through which FDI affects growth. Our contribution is thus threefold. First we examine the role the financial environment played in the effective absorption of FDI and its impact on the growth of the Ghanaian economy. Second, we examine the role the financial structure in Ghana played in the relationship between FDI and growth, and finally, we examine how relevant these constituents in the financial system are in the short run and in the long run. These issues to the best of our knowledge have not been addressed in Ghana.

The findings of this study will provide relevant policy direction with regards to attracting FDI and absorb its full benefit. It will further shed light on the extent to which the fast-growing Ghanaian financial system can provide the requisite platform for FDI to have an effective impact on economic growth in Ghana. Moreover, by disaggregating the financial structure into capital market and banking sector, this study will identify which aspect provides a better channel for achievement of growth through FDI. This will enable policy makers to channel more resources to that particular sector. Also with regards to the policy direction, the results from this study will enable policy makers to assess whether the incentives provided by government to attract FDI are worthwhile and to provide the right platform to harness the benefits from the expected increase of FDI inflow especially due to the recent oil exploration in Ghana.

The remainder of this paper is organised as follows: In Section 2, we review literature on FDI, Growth and Financial Development. Sections 3 and 4 discuss the data and the methods being used. In Section 5, we analyse the data and conclusion in Section 6.

\section{Review on FDI, Growth and Financial Development}

FDI generally is defined as a lasting interest in management (normally $10 \%$ of voting rights) in a firm that is operated in a country other than that of the investor's country of residence [9]. FDI can take two forms: the first is the mortar and bricks investment and the second, mergers and acquisition. Unlike the former that represents a completely new investment, the latter involves a foreign firm purchasing an interest in a firm that is already established. Most developing countries make several attempts to attract FDI. Indeed, most of their policies for development have been targeted towards attracting FDI. These countries usually provide incentives, sometimes in the form of a tax reduction for the foreign companies. This is usually in expectation that the activities of FDI

\footnotetext{
${ }^{1}$ See also for example, Harrison and McMillan [5].
} 
will help promote growth in the host country.

Existing literature has suggested two channels by which FDI can promote economic growth. These two channels can be direct or indirect. With the direct channel, FDI can contribute to growth through capital formation. Capital formation can affect growth either directly or indirectly. From a theoretical perspective, the production function is given by $Q=f(L, K)$, where $Q$ signifies output, and, $L$ and $K$ are labour and capital respectively. Since FDI involves capital stock accumulation, an increase in FDI implies an increase in capital which will then increase output. This direct impact however does not give a complete view of how FDI impacts on growth. Thus, we extend our discussion beyond this and discuss the second channel which is the indirect impact. The indirect impact makes it possible for us to identify the channels through which FDI can affect growth. These channels include competition, linkages, skills and imitation.

Caves's [10] seminal work on various industries confirms this pattern. In his study, he finds a positive relationship between the productivity of a multinational enterprise and the average output per worker of the domestic firms operating in the same industry. Findlay [11] also found FDI to be useful in providing technical assistance in host countries through the transfer of improved technology and good management practices by the foreign firms. In comparing the influence of FDI to domestic investment, Borensztein et al. [12] assert that FDI facilitates growth better than domestic investment. To Rappaport [13], the impact of FDI on productivity is not just limited to the firms that have received the investment but also to all firms in the host country.

Following the results from these studies, we can conclude that FDI can have a positive impact on growth through positive externalities. However as emphasized by Nguyen et al. [14], host countries will benefit from these externalities through host countries' absorptive capacity. It is therefore important for developing countries to think more about their capacity to absorb before providing incentives to attract FDI. Of course, it can even be expected that countries with a high absorptive capacity might attract not just more FDI but also high quality ones. Indeed, a study by Girma [15] suggests that absorptive capacity of host country will facilitate spillovers from multinational firms. Generally, in relation to how FDI influences growth, we can classify absorptive capacity into domestic firms' ability to absorb and the national capacity to absorb.

Regarding the domestic factors, Cohen and Levinthal [16] indicate in their study that firms need to have a certain level of knowledge for them to be able absorb new knowledge. Since Knowledge capacity is proxied by technology it means that the technological gap between the host country and the foreign country should be small [17] for FDI to be beneficial to host countries. The quality of labour force proxied by education is another domestic factor necessary for absorbing the benefits of FDI [18]. A high level of research and development can also help to make use of knowledge brought in by FDI [16]. Borensztein et al. [12] also suggest that workers who are motivated and well-trained are needed to complement new technology brought by FDI. To them, the adoption of new technology can only be beneficial to domestic firms if they have some appreciable level of education to understand what is required of them. The national factors include the level of institutional and financial development. According to Kalotay [19], friendly investment policies will help host countries absorb what FDIs bring. Durham [20] however focuses on how businesses are regulated, property rights protection, financial development and low corruption levels as measurement for good institutions. Finally, Hermes and Lensink [21] suggest that a well-developed financial system helps diffuse the benefits of FDI.

The positive relationship found between FDI and growth has not come without criticisms. A number of studies have found a negative relationship between these two. Among these studies, the most vital ones are Durham [20], Lyroudi et al. [22], Carkovic and Levine [23] and Lipsey [24]. Durham [20] after studying a panel formed by 80 countries in member and non-member OECD in the period 1970-1980 find a negative relation between FDI and growth but maintain that financial and institutional absorptive capacity play a vital role in FDI's effect on growth. Kholdy [25] applies Granger causality test on 10 economies from Eastern Asia and obtains similar results. In the same vein, Lyroudi et al. [22] demonstrates a negative relation between FDI and growth through the Bayesian analysis and Carkovic and Levine [23] also find negative results between the two but go on to take into account education, economic and commercial development in the host country after their disappointing results. On Ghana, Frimpong and Oteng-Abayie [2] find a negative impact of FDI on GDP growth of Ghana in the short run and the long run. Asiedu [3] also concludes that the effect of FDIs through spillovers in areas of production, technology transfers and job creation have still not been realised. Similarly, Waldkirch and Ofosu [4] find a negative effect of the presence of FDI on domestically-owned firms in Ghana.

Recent strand of literature indicates that the architecture of the financial system plays a significant role in determining whether the presence of FDI promotes growth or not. The architecture of the financial system can spur 
growth in specific sectors in the economy. This is because firms in some sectors thrive better when there are some specific forms of external finance available from the financial system [26]-[29]. Furthermore, research about the relevance of the financial structure has highlighted its importance to economic growth [30]-[32]. Thus, it is also possible for the role of financial markets on the relationship between FDI and growth to differ between a system that is mainly dominated by banks and that which is dominated by capital markets. In addition, the institutional and legal framework of the financial system can influence the relationship between FDI and growth [33]-[35].

It is obvious from the latter discussion that failure to take into account the absorptive capacity of a country is what usually results in a negative relationship between FDI and growth. Hence, despite the negative results obtained in these studies, our study focuses mainly on one of the mediums through which FDI can influence growth. Specifically, we examine whether well-developed financial systems can facilitate economic growth in Ghana. Unlike previous studies, we disaggregate the financial system into its two main components; capital markets and banks. We do this to find out which of these two is more relevant for growth.

\section{Methodology}

To achieve our objectives, we make use of the Autoregressive Distributed Lag (ARDL) model introduced by Pesaran et al. [36]. This technique incorporates both $\mathrm{I}(1)$ and $\mathrm{I}(0)$ variables in the same estimation. The ARDL works under a certain precondition. This precondition requires none of the variable to be $I(2)$. In view of this, this study checks the optimal lag length required to conduct the Augmented Dickey-Fuller (ADF) test which will enable us determine the order of integration of the variables. The Akaike Information Criteria (AIC), the Schwartz Bayesian Criteria (SBC) and the Hannah Quinnon Information Criterion (HQC) are used to determine the optimal lag length for conducting stationarity test on each of the variables. Next, to satisfy the preconditions of the ARDL model, we conduct the ADF test. The null hypothesis for the ADF test is that unit root is present in the series whilst the alternate states that unit root is not present in the variables. We make our decision on stationarity by comparing the critical value to the t statistics. Our decision will be based on the $5 \%$ critical value. Once all the variables are confirmed to be either I(0) or I(1), we estimate the ARDL model. We check whether cointegration exists among the variables and estimate an Error Correction Model once cointegration is established. Otherwise, we stick to the estimation of the short run equation.

Following Pesaran et al. 2001 [36], we estimate the following Autoregressive Distributed Lag (ARDL) model which represents our baseline model

$$
\begin{aligned}
\Delta Y_{t}= & \alpha_{0}+\sum_{i=1}^{k} \beta_{i} \Delta Y_{t-1}+\sum_{i=1}^{k} \gamma_{i} \Delta(\mathrm{FDI})_{t-1}+\sum_{i=1}^{k} \theta_{i}+\sum_{i=1}^{k} \varphi_{i} \Delta(\mathrm{FIN})_{t-1} \\
& +\sum_{i=1}^{k} \phi_{i} \Delta(\mathrm{CONT})_{t-1}+\delta_{1} Y_{t-1}+\delta_{2} F D I_{t-1}+\delta_{4}(\mathrm{FIN})_{t-1}+\delta_{5}(\mathrm{CONT})_{t-1}+\varepsilon_{t}
\end{aligned}
$$

where $Y$ is growth of real per capita GDP per capita, FDI is net inflow of investment, FIN is financial development, CONT includes other control variables that include initial income, government consumption, population and financial reforms, $K$ is the number of lags, $\Delta$ is the difference operator, $t$ is years and is the error term.

Equation (1) will help achieve objective 1 which seeks to find whether FDI or financial development plays a role in the Ghana's growth process.

$$
\begin{aligned}
\Delta Y_{t}= & \alpha_{0}+\sum_{i=1}^{k} \beta_{i} \Delta Y_{t-1}+\sum_{i=1}^{k} \gamma_{i} \Delta(\mathrm{FDI})_{t-1}+\sum_{i=1}^{k} \theta_{i}(\mathrm{FDI} * \mathrm{FIN}) \\
& +\sum_{i=1}^{k} \varphi_{i} \Delta(\mathrm{FIN})_{t-1}+\sum_{i=1}^{k} \phi_{i} \Delta(\mathrm{CONT})_{t-1}+\delta_{1} Y_{t-1}+\delta_{2} \mathrm{FDI}_{t-1} \\
& +\delta_{3}(\mathrm{FDI} * \mathrm{FIN})_{t-1}+\delta_{4}(\mathrm{FIN})_{t-1}+\delta_{5}(\mathrm{CONT})_{t-1}+\varepsilon_{t}
\end{aligned}
$$

To achieve objective 2 which seeks to find which of the constituents of the financial structure helps FDI to promote growth, we augment equation modify Equation (1) to get Equation (2). In Equation (2), we include our main variable of concern, which is the interaction of FDI and FIN. Given the way the variable FIN (bank development/(bank development + stock market development)) is measured, a negative sign attached to $\varphi_{i}$ will signify that stock market development and not bank development facilitates growth because a decrease in one implies an increase in another. In the short run, we expect bank development to promote growth while in the long run the stock market is expected to promote growth. We also expect the coefficients on trade and government expenditure to be positive and the coefficient on population growth to be negative since the dependent variable is GDP per capita growth. 
As a robustness check, we use another measure of financial development, ratio of bank asset to sum of bank asset, stock market capitalisation and bond market capitalisation to see whether our results are consistent.

\subsection{Data}

The study employs data from different sources over the period 1977-2012. It measures the level of financial development using data from World Bank [37]. This is required to investigate our objectives. There are several ways used to measure bank development. These include the ratio of private sector credit to GDP which captures the activities of banks and the ratio of monetary aggregates to GDP which signifies financial depth. These measures offer a better indication of the size and quality of services provided by the financial system because they focus on credit issued to the private sector. However, as Levine et al. [38] put it, neither private credit nor financial depth can adequately assess the effectiveness of financial intermediaries in smoothing market frictions and channeling funds to the most productive use. As a result, we use the ratio of bank assets to GDP to measure the level of financial development. Apart from it being a good measure for bank development, our interest lies in this variable as it provides more years of available data.

The most commonly used measures of stock market development are the market capitalization ratio [39]-[41], stock market activity [42]-[44], and turnover ratio [45]-[47]. We use the ratio of stock market capitalisation to GDP because it captures the size and activity of the financial market especially in the mobilisation and allocation of funds in the financial system and also due to data availability constraints. Apart from these, as Demigurc-Kunt and Levine [48] put it, this measure is less arbitrary than any other measure of stock market development. Market capitalization refers to the overall size of the stock market and is defined as the total value of listed shares relative to the GDP.

Using these two indicators for bank development and stock market development, we develop a unique measure of financial development in Ghana. To construct this indicator, we use a measure of the banking sector activity in relation to the sum of the banking activity measure and the non-bank financial sector to get a non-bias measure. We employ the stock market as the representation for the capital market or non-bank financial activity.

Data on FDI is taken from World Development Indicators (WDI). World Bank defines this indicator as the net inflows of investment to acquire a lasting management interest of $10 \%$ or more of voting stock in an enterprise. This investment must be done by people of nationals other than the investing country. It includes equity capital, reinvestment of earnings, other long term capital and short term capital which they obtain from the balance of payment of the reporting country. For data on Growth of output we use the real GDP per capita growth from WDI. We include a host of other variables as has been used in this area of research and more importantly to control for missing variable bias. These variables include openness, population and government expenditure.

Before discussing the main results, we present some trend analysis on Ghana's FDI.

\subsection{Trends in FDI Inflow in Ghana}

A look at Ghana's FDI (Figure 1) trend reveals some interesting pattern. Ghana's net FDI as a percentage of

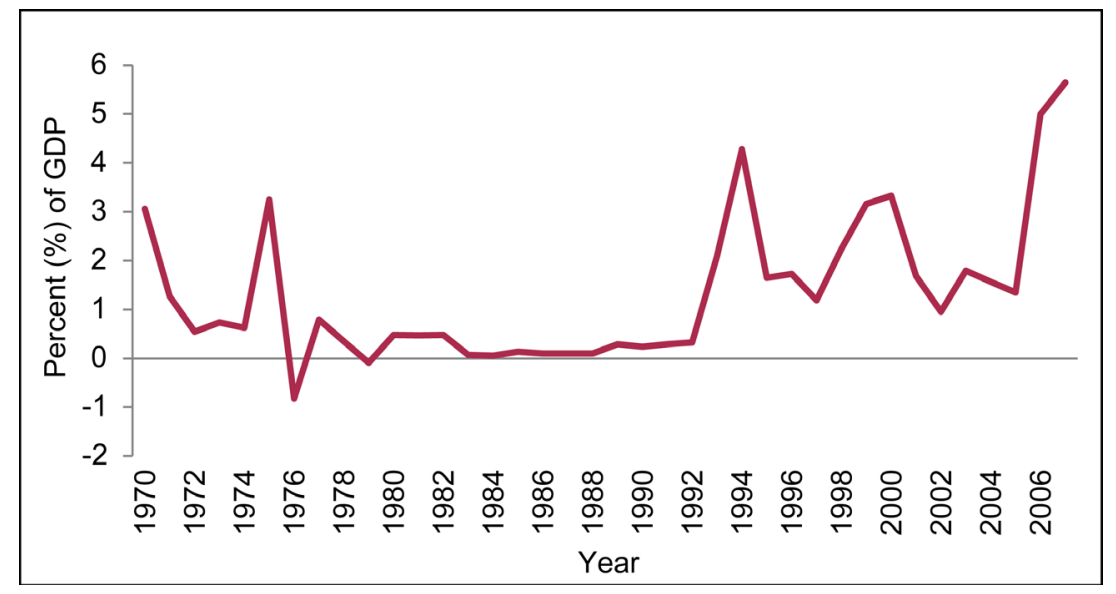

Figure 1. FDI Trends (1970-2009). 
GDP was about 3\% of GDP in the 1970 but dropped sharply to negative in 1976. This percentage was very low and was a result of the Marxist-Leninist view inherited in the 1960s during the Nkrumah regime coupled with the overthrow of the democratic government in 1972. The attitude posed by the new military government towards external debts together with their socialists view put off a large number of foreign investors.

This resulted in a sharp slump of FDI inflow. The country did not emerge from this prolonged slump until about the early 1990s when giant strides were made in getting FDI into the country. The ongoing democratic environment which started in the early 1990s has among other things provided further assurance for foreign investors. This surge although not constant remains higher than in the previous decades.

\section{Analysis of Results}

As indicated in the methodology, we select our optimal lag length using the AIC, the SBC and the HQC. From Table 1, the AIC, SBC and HQC select an optimal lag length of 1 for Real GDP Growth, Foreign Direct Investment, Government Expenditure, Trade and Financial Reforms whereas an optimal lag length of 2 is selected for Population Growth Rate, Bank Development and the interaction of Bank Development and FDI. Subsequently, in accordance with the requirement for the bound cointegration test, we carry out unit root tests to ensure that none of the series is integrated of order 2 or higher.

As explained in section 4, we use both the augmented Dickey-Fuller (ADF) (1979) and Phillips-Perron (PP) (1988) unit root tests for this purpose and summarise the results in Table 2. The null of both tests indicate the presence of unit roots.

Table 1. Unit root tests.

\begin{tabular}{|c|c|c|c|c|c|}
\hline \multirow{2}{*}{ Variables } & \multicolumn{2}{|c|}{ ADF Test Statistic (No Constant) } & \multicolumn{2}{|c|}{ PP Test Statistics (No Constant) } & \multirow{2}{*}{$\begin{array}{l}\text { Optimal Lag Length } \\
\text { (Based on SBIC) }\end{array}$} \\
\hline & Level & First Difference & Level & First Difference & \\
\hline Real GDP Growth & $-2.513^{* *}$ & $-8.095^{* * *}$ & $3.194 * * *$ & $-9.746^{* * *}$ & 1 \\
\hline Real GDP Per Capita Growth & $-3.403 * * *$ & $-7.889 * * *$ & $-4.224 * * *$ & $-8.727^{* * *}$ & 1 \\
\hline Foreign Direct Investment & 1.852 & $-2.144 * *$ & 1.265 & $-6.571^{* * *}$ & 1 \\
\hline Government Spending (\%GDP) & -0.141 & $-5.615^{* * *}$ & -0.070 & $-6.148^{* * *}$ & 1 \\
\hline Trade (\% of GDP) & -0.097 & $-5.450 * * *$ & -0.066 & $-5.612^{* * *}$ & 1 \\
\hline Population Growth Rate & -1.288 & $-4.420 * * *$ & -0.906 & $-3.075 * * *$ & 2 \\
\hline Bank Development 1 & -0.830 & $-4.067 * * *$ & -0.802 & $-4.912^{* * *}$ & 2 \\
\hline Bank Development 2 & 0.000 & $-6.403 * * *$ & -- & $-13.837 * * *$ & 2 \\
\hline Financial Reforms & -1.257 & $-5.437 * * *$ & -1.314 & $-7.478 * * *$ & 1 \\
\hline Bank Development 1 FFDI & 1.848 & $-2.039 * *$ & 0.326 & $-7.471 * * *$ & 2 \\
\hline Bank Development 2*FDI & 1.852 & $-2.144 * *$ & 1.265 & $-6.571 * * *$ & 2 \\
\hline
\end{tabular}

${ }^{* * *} p<0.01,{ }^{* *} p<0.05,{ }^{*} p<0.1$ denotes level of significance at $1 \%, 5 \%$ and $10 \%$ respectively. The optimal lag structure is determined by SBIC.

Table 2. Diagnostic test results.

\begin{tabular}{|c|c|c|c|c|c|c|}
\hline \multirow{2}{*}{ Tests } & \multicolumn{2}{|c|}{ MODEL (1) } & \multicolumn{2}{|c|}{ MODEL (2) } & \multicolumn{2}{|c|}{ MODEL (3) } \\
\hline & \multicolumn{2}{|c|}{ ARDL ( $\left(\begin{array}{llll}1 & 1 & 1 & 1\end{array}\right)$} & \multicolumn{2}{|c|}{ ARDL (1 11111222 2) } & \multicolumn{2}{|c|}{ ARDL (1 11112222 1) } \\
\hline A. Serial Correlation & $\operatorname{Chi}^{2}(1)$ & $9.488(0.002)$ & $\operatorname{Chi}^{2}(1)$ & $5.612(0.018)$ & $\operatorname{Chi}^{2}(1)$ & $6.822(0.090)$ \\
\hline B. ARCH & $\operatorname{Chi}^{2}(1)$ & $0.844(0.358)$ & $\operatorname{Chi}^{2}(1)$ & $0182(0.670)$ & $\operatorname{Chi}^{2}(1)$ & $0.318(0.573)$ \\
\hline C. Heteroscedasticity & $\operatorname{Chi}^{2}(1)$ & $2.76(0.097)$ & $\operatorname{Chi}^{2}(1)$ & $4.13(0.420)$ & $\operatorname{Chi}^{2}(1)$ & $5.29(0.061)$ \\
\hline D. Functional Form & $F(3,19)$ & $2.09(0.135)$ & $\mathrm{F}(3,12)$ & $2.00(0.168)$ & $\mathrm{F}(3,10)$ & $1.26(0.343)$ \\
\hline
\end{tabular}

Notes: The probability values for the diagnostic tests are given in parenthesis. A: Breusch-Godfrey Lagrange Multiplier test of residual serial correlation. Operates under the null of no serial correlation. B: Lagrange Multiplier test for Autoregressive conditional heteroscedasticity: operates under the null of no ARCH effect. C: Breusch-Pagan/Cook Weisberg for constant variance based on the regression of squared residuals on fitted values. Operates under the null of constant variance. D: Ramsey’s Test using squares of the fitted values. Operates under the null of correct functional form. 
From Table 1 above, it is evident from both the ADF and the PP tests that all the explanatory variables are integrated of order 1 and thus stationary at their first difference. The dependent variable however (both Real GDP growth and real GDP per capita growth) is found to be stationary at levels and thereby integrated of order 0 .

\subsection{Long Run Estimation Results}

Table 2 below shows the results of the diagnostic tests for all three models. These tests include test for normality, autocorrelation and heteroscedasticity. In Table 2, all models show the absence of heteroscedasticity and also show that the correct functional form has been specified. Models 1 and 2 show some signs of serial correlation but model 3 show no evidence of serial correlation.

Having satisfied the requirement of the bound cointegration test, that is, having all variables being at most I(1), we examine the presence of a long run relationship among the variables over the period 1976 to 2009 in Ghana. The results of the bound test are given in Table 3 below. It is clear that the F-statistic is above the critical value at the $5 \%$ level of significance calculated by Pesaran et al. [36]. This indicates the presence of a long-run relationship among the variables.

Next, we present our long-run results in Table 4 below. Column 1 of Table 4 shows our baseline estimation without the interaction of the Bank Development indicator and FDI. From the results, we only find Foreign

Table 3. Pesaran/Shin/Smith (2001) [4] bounds tests for LR ARDL model.

\begin{tabular}{cccccccccc}
\hline & & \multicolumn{6}{c}{ Critical Values } \\
\cline { 3 - 9 } MODEL & \multirow{2}{*}{ ARDL } & F-STAT & \multicolumn{2}{c}{$\mathbf{1 0 \%}$} & \multicolumn{2}{c}{$\mathbf{5 \%}$} \\
\cline { 3 - 9 } & & & Lower Bound & Upper Bound & Lower Bound & Upper Bound & Lower Bound & Upper Bound \\
\hline$(1)$ & $(11112)$ & 4.870 & 2.26 & 3.35 & 2.62 & 3.79 & 3.41 & 4.68 \\
$(2)$ & $(1111222)$ & 6.409 & 2.12 & 3.23 & 2.45 & 3.61 & 3.15 & 4.43 \\
$(3)$ & $(11114221)$ & 5.762 & 2.03 & 3.13 & 2.32 & 3.50 & 2.96 & 4.26 \\
\hline
\end{tabular}

$H_{0}$ : No Levels Relationship. Accept if $F<$ critical Value for lower bound. Reject if $F>$ critical value for upper bound.

Table 4. Estimated long run coefficients based on ARDL approach (1 111112122221$)$.

\begin{tabular}{|c|c|c|c|}
\hline \multirow{2}{*}{ Regressors } & \multicolumn{3}{|c|}{ Dependent Variable: GDP Growth } \\
\hline & (1) & (2) & (3) \\
\hline \multirow[t]{2}{*}{ Foreign Direct Investment (\% of GDP) } & $0.565^{*}$ & 2.645 & 3.759 \\
\hline & $(0.278)$ & $(2.140)$ & $(2.382)$ \\
\hline \multirow[t]{2}{*}{ Government Expenditure (\% of GDP) } & -0.609 & $-1.131 *$ & $-1.116^{*}$ \\
\hline & $(0.328)$ & $(0.596)$ & $(0.598)$ \\
\hline \multirow[t]{2}{*}{ Trade (\% of GDP) } & 0.046 & $0.094 * * *$ & $0.177^{* *}$ \\
\hline & $(0.024)$ & $(0.031)$ & $(0.076)$ \\
\hline \multirow[t]{2}{*}{ Population Growth Rate (\%) } & 3.175 & -3.399 & -4.819 \\
\hline & (3.982) & (4.664) & (5.119) \\
\hline \multirow[t]{2}{*}{ BANKDEV1*FDI } & & -5.684 & $-8.600^{*}$ \\
\hline & & (3.780) & $(4.603)$ \\
\hline \multirow[t]{2}{*}{ BANKDEV1 } & -0.292 & 6.864 & 9.785 \\
\hline & $(0.949)$ & $(6.865)$ & $(7.484)$ \\
\hline \multirow[t]{2}{*}{ Financial Reform } & & & -0.512 \\
\hline & & & $(0.4112)$ \\
\hline R-Squared & 0.686 & 0.857 & 0.836 \\
\hline Adjusted R-Squared & 0.500 & 0.686 & 0.638 \\
\hline Number of Observations & 36 & 34 & 34 \\
\hline
\end{tabular}

Standard errors in parentheses. ${ }^{* * *} p<0.01,{ }^{* *} p<0.05,{ }^{*} p<0.1$ denotes level of significance at $1 \%, 5 \%$ and $10 \%$ respectively. 
Direct Investment to be significant and positive, implying that FDI promotes growth. The rest of the variables are not significant. In Column 2, we incorporate the interaction of bank development and FDI and present the results. We find that both bank development and FDI do not promote growth in the long run on their own as their coefficients are not statistically significant. We also do not find their interaction to be statistically significant, indicating that FDI in the presence of a well-developed bank system does not promote growth.

Both trade and government expenditure becomes statistically significant. More specifically, while government expenditure as a percentage of GDP has a negative and significant impact on GDP growth in the long run, trade has a positive impact in the long run. These results are consistent with our expectations.

Large amounts of spending by government in the long run makes a country indebted and becomes detrimental to a country's growth as more of its resources will be diverted from other activities and be used to service the debt. With the trade variable, an increase in the volume of trade promotes growth. Including the financial reform variable which measures institutional quality in the next estimation reveals some interesting results. We present this result in Table 4 column 3. We still find bank development and FDI not to be statistically significant. However, their interaction in this particular estimation is significant and negative. As our bank development variable is measured as the ratio of bank development to the sum of bank development and capital market development, the negative sign reveals the important and complementary role played by the capital market in the long run. In effect, FDI will have its desired impact in the long run in the presence of a well-developed capital market.

\subsection{Short Run Effect}

Table 5 column 1shows the short run results of our baseline regression. From our baseline estimation results, the speed of adjustment is $92 \%$. This means that any deviation from the long-run equilibrium will take approximately 11 months to be restored. Unlike the long run estimation result, government expenditure has a statistically significant impact on growth in the short run. This impact unlike that of the long run is positive, implying that in the short run government expenditure promotes growth.

All the other regressors in the baseline estimation result are not significant. In model 2, where we include our main variable of concern, the interaction of FDI and bank development, we find that the results are improved. Government expenditure maintains its statistical significance and its sign. This means that growth is contemporaneously affected in a negative way when there is change in government expenditure. Trade is significant but negative implying that the gains from trade cannot be realized in the short run. Growth is not contemporaneously affected by population. However, population has a negative delayed effect on growth. Interestingly, the results show that both contemporaneous bank development and FDI do not have any impact on growth. Rather, what we see in Table 5 is that the delayed effect of bank development has an impact on growth and this impact is negative.

Given the way we define our bank development variable; this implies that the delayed effect of the capital market has good implications for growth. Our main variable of concern is positive and significant even though its constituent variables are not. The positive sign indicates that the contemporaneous effect of bank development interacted with FDI has a positive influence on growth.

\subsection{Discussion of Results}

Our results so far have revealed some important findings. First, our results have generally revealed the importance of financial systems in facilitating the output effect of FDI in Ghana. Setting up a business always requires some form of costs which can be financed partly financial institutions and markets. Frictions that exist in financial systems will cause a gap between the lending rate and the borrowing rate. Well-developed financial systems can reduce the gap between the savings rate and the lending rate, thus foreign investors can borrow at a relatively lower cost to pursue their goals.

The results have also shown the specific roles played by the different components of the financial system in helping FDI to achieve its desired output effect. One important thing observed in the results is that, while both FDI and capital markets do not influence growth on their own, the growth effects of FDI is achieved in the long run when the capital market is well-developed. These results are consistent with Alfaro et al. [6] who find that bank development enhances the growth effects of FDI. The difference between our study and Alfaro et al. [6] is that they do not distinguish between the long run and the short run. We offer several explanations for our 
Table 5. Estimates of the Error Correction Representation—ARDL Model (1 11112222 1).

\begin{tabular}{|c|c|c|c|}
\hline \multirow{2}{*}{ Regressors } & \multicolumn{3}{|c|}{ Dependent Variable: GDP Growth Rate } \\
\hline & (1) & (2) & (3) \\
\hline \multirow[t]{2}{*}{ ECM $(-1)$} & $-0.923 * * *$ & $-0.956 * * *$ & $-0.962 * * *$ \\
\hline & $(0.226)$ & $(0.199)$ & $(0.201)$ \\
\hline \multirow[t]{2}{*}{ Foreign Direct Investment (\% of GDP) = D, } & 0.536 & -0.540 & -1.406 \\
\hline & $(0.600)$ & $(1.319)$ & $(1.478)$ \\
\hline \multirow[t]{2}{*}{ Government Expenditure (\% of GDP) = D, } & $1.144 * *$ & $1.146^{* *}$ & $1.188 * *$ \\
\hline & $(0.536)$ & $(0.511)$ & $(0.545)$ \\
\hline \multirow[t]{2}{*}{ Trade $(\%$ of GDP) = D, } & -0.082 & $-0.137 * *$ & $-0.169 * *$ \\
\hline & $(0.060)$ & $(0.056)$ & $(0.066)$ \\
\hline \multirow{2}{*}{ Population Growth \% = D, } & 6.801 & -10.488 & -14.311 \\
\hline & $(14.327)$ & $(13.766)$ & $(14.865)$ \\
\hline \multirow[t]{2}{*}{ Population Growth \% = L, } & -18.811 & $-0.329 * *$ & 5.481 \\
\hline & $(17.310)$ & $(16.702)$ & (18.143) \\
\hline \multirow{2}{*}{ BANKDEV1*FDI = D, } & & $5.232 * *$ & $7.429 * *$ \\
\hline & & $(2.437)$ & (2.987) \\
\hline \multirow[t]{2}{*}{ BANKDEV1*FDI = L, } & & $2.593^{* *}$ & $3.203^{* * *}$ \\
\hline & & $(0.911)$ & $(1.051)$ \\
\hline \multirow[t]{2}{*}{ BANKDEV1 = D, } & 2.162 & -1.679 & -5.227 \\
\hline & (5.054) & $(4.900)$ & (5.609) \\
\hline \multirow[t]{2}{*}{ BANKDEV1 = L, } & -5.805 & $-11.641^{*}$ & $-12.316^{*}$ \\
\hline & (6.698) & $(6.580)$ & $(6.670)$ \\
\hline \multirow[t]{2}{*}{ Financial Reform = D, } & & & 0.178 \\
\hline & & & $(0.365)$ \\
\hline \multirow[t]{2}{*}{ Constant } & 3.014 & 14.366 & 14.460 \\
\hline & (13.362) & (12.795) & (13.001) \\
\hline R-Squared & 0.714 & 0.857 & 0.836 \\
\hline Adjusted R-Squared & 0.571 & 0.686 & 0.638 \\
\hline Number of Observations & 37 & 34 & 34 \\
\hline
\end{tabular}

Standard errors in parentheses. ${ }^{* *} p<0.01,{ }^{* *} p<0.05,{ }^{*} p<0.1$ denotes level of significance at $1 \%, 5 \%$ and $10 \%$ respectively.

interesting result. First, we believe that FDI, which is a form of long-term investment, will thrive better in an environment with a well-developed capital which makes available long term finance. FDI can raise money from the capital market if foreign investors want to finance part of their investment from the capital market. A well-developed capital market can help foreign investors recover their investment quickly if they want to sell their shares. Second, given that foreign investors can partly invest through purchasing existing equity, the liquidity of stock markets will likely rise together with the assurance of a continuous form of long term finance for the foreign investors. Many more people will be willing to participate in the capital market because of this increased liquidity and this will in turn increase the value traded domestically. All these are necessary for 
growth to be realized. In sum, FDI can complement the capital market to influence growth in the long run. Second, we have shown that in the short run, it is rather bank development that FDI needs to achieve growth. This result is also not surprising as in the short run one would expect banks to readily provide funds for the foreign investors.

\subsection{Summary and Conclusion}

This study has examined how FDI influences economic growth through the financial environment. A key strength of the study is that it adopts a measure which captures the ratio of bank development to the sum of bank development and stock market development and interacts it with FDI to examine how FDI in the presence of a sound financial environment influences growth. In other words, the different components of financial development are taken into account in this study. Our study has shown that without bank development, FDI will have no impact on growth in the short run. In other words, in the short run, it is bank development that will drive FDI to influence growth. Our study also has shown that in the long run, it is rather capital market development and not bank development that will promote growth. These results have important policy directions. First, policymakers should continue developing the financial environment to make FDI relevant to growth, for as the results suggest, bank development is needed to make FDI influence growth in the short run. Second, development of the capital market should still continue so that FDI will have a sound environment to thrive.

\section{Acknowledgements}

We acknowledge the support given to us by the Business School, College of Humanities, University of Ghana, Legon, Accra, Ghana, as well as our colleagues who peer-reviewed a draft of this paper before it was submitted for consideration.

\section{References}

[1] World Bank (2006) World Bank Development Report. Washington DC.

[2] Frimpong, J.M. and Oteng-Abayie, E.F. (2006) Bounds Testing Approach: An Examination of Foreign Direct Investment, Trade, and Growth Relationships. MPRA Paper No. 352. http://mpra.ub.uni-muenchen.de/352/10

[3] Asiedu, E. (2006) Foreign Direct Investment in Africa: The Role of Natural Resources, Market Size, Government Policy, Institutions and Political Instability. The World Economy, 29, 63-77. http://dx.doi.org/10.1111/j.1467-9701.2006.00758.x

[4] Waldkirch, A. and Ofosu, A. (2010) Foreign Presence, Spillovers, and Productivity: Evidence from Ghana. World Development, 38, 1114-1126. http://dx.doi.org/10.1016/j.worlddev.2009.12.020

[5] Harrison, A., Love, I. and McMillan, M. (2004) Global Capital Flows and Financing Constraints. Journal of Development Economics, 75, 269-301. http://dx.doi.org/10.1016/j.jdeveco.2003.10.002

[6] Alfaro, L., Chanda, A., Kalemli-Ozcan, S. and Sayek, S. (2003) FDI and Economic Growth, The Role of Local Financial Markets. Journal of International Economics, 64, 113-134.

[7] Asiedu, E. (2002) On the Determinants of Foreign Direct Investment to Developing Countries: Is Africa Different? World Development, 30, 107-119. http://dx.doi.org/10.1016/S0305-750X(01)00100-0

[8] Alfaro, L., Chanda, A., Kalemli-Ozcan, S. and Sayek, S. (2006) How Does Foreign Direct Investment Promote Economic Growth? Exploring the Effects of Financial Markets on Linkages. NBER Working Paper 12522.

[9] World Bank (1996) World Debt Tables: External Finance for Developing Countries. Vol. 1, Analysis and Summary Tables, Washington D.C.

[10] Caves, R.E. (1974) Multinational Firms, Competition and Productivity in Host Country Markets. Economica, 41, 176193. http://dx.doi.org/10.2307/2553765

[11] Findlay, R. (1978) Relative Backwardness, Direct Foreign Investment, and the Transfer of Technology: A Simple Dynamic Model. The Quarterly Journal of Economics, 92, 1-16. http://dx.doi.org/10.2307/1885996

[12] Borenztein, E., De Gregori, J. and Lee, J.-W. (1998) How Does Foreign Direct Investment Affect Economic Growth? Journal of International Economics, 45, 115-135. http://dx.doi.org/10.1016/S0022-1996(97)00033-0

[13] Rappaport, J. (2000) How Does Openness to Capital Flows Affect Growth? Mimeo, Federal Reserve Bank of Kansas City, Kansas City.

[14] Nguyen, A.N., Nguyen, T.L., Dand, T.P., Quang, N., Nguyen, D.C. and Nguyen, D.N. (2008) Foreign Direct Invest- 
ment in Vietnam: Is There Any Evidence of Technological Spillover Effects? Development and Policies Research Working Paper, Hanoi.

[15] Girma, S. (2005) Absorptive Capacity and Productivity Spillovers from FDI: A Threshold Regression Analysis. Oxford Bulletin of Economics \& Statistics, 67, 281-306. http://dx.doi.org/10.1111/j.1468-0084.2005.00120.x

[16] Cohen, W.M. and Levinthal, D.A. (1990) Absorptive Capacity: A New Perspective on Learning and Innovation. Administrative Science Quarterly, 35, 128-152. http://dx.doi.org/10.2307/2393553

[17] De Mello, L.R. (1997) Foreign Direct Investment in Developing Countries and Growth: A Selective Survey. The Journal of Development Studies, 34, 1-34. http://dx.doi.org/10.1080/00220389708422501

[18] Blomström, M. and Kokko, A. (2003) Human Capital and Inward FDI: European Commission under the Training and Mobility of Researchers Programme. Working Paper 167.

[19] Kalotay, K. (2000) Is the Sky the Limit? The Absorptive Capacity of Central Europe for FDI. Transnational Corporations, 9, 137-162.

[20] Durham, J.B. (2004) Absorptive Capacity and the Effects of Foreign Direct Investment and Equity Foreign Portfolio Investment on Economic Growth. European Economic Review, 48, 285-306. http://dx.doi.org/10.1016/S0014-2921(02)00264-7

[21] Hermes, N. and Lensink, R. (2003) Foreign Direct Investment, Financial Development and Economic Growth. Journal of Development Studies, 40, 142-163. http://dx.doi.org/10.1080/00220380412331293707

[22] Lyroudi, K., Papanastasiou, J. and Vamvakidis, A. (2004) Foreign Direct Investment and Economic Growth in Transition Economies. South Eastern Journal of Economics, 1, 97-110.

[23] Carkovic, M. and Levine, R. (2002) Does Foreign Direct Investment Acelerate Economic Growth? Working Paper, University of Minnesota, Minneapolis and Saint Paul.

[24] Lipsey, R.E. (2006) Measuring the Impacts of FDI in Central and Eastern Europe. NBER Working Paper Series, No. 12808.

[25] Kholdy, S. (1995) Causality between Foreign Investment and Spillover Efficiency. Applied Economics, 27, 745-749. http://dx.doi.org/10.1080/00036849500000064

[26] Manova, K. (2008) Credit Constraints, Equity Market Liberalisations and International Trade. Journal of International Economics, 76, 33-47. http://dx.doi.org/10.1016/j.jinteco.2008.03.008

[27] Hur, J., Raj, M. and Riyanto, Y. (2006) The Impact of Financial Development and Asset Tangibility on Export. World Development, 34, 1728-1741. http://dx.doi.org/10.1016/j.worlddev.2006.02.003

[28] Braun, M. (2003) Financial Contractibility and Asset Hardness. UCLA, Mimeo.

[29] Allen, F., Qian, J. and Qian, M.J. (2005) Law, Finance, and Economic Growth in China. Journal of Financial Economics, 77, 57-116. http://dx.doi.org/10.1016/j.jfineco.2004.06.010

[30] Tadesse, S. (2001) Financial Architecture and Economic Performance: International Evidence. William Davidson Institute Working Papers Series 449, William Davidson Institute at the University of Michigan, Ann Arbor.

[31] Rajan, R. and Zingales, L. (1998) Financial Dependence and Growth. The American Economic Review, 88, 559-586.

[32] Luintel, K.B., Khan, M., Arestis, P. and Theodoridis, K. (2008) Financial Structure and Economic Growth. Journal of Development Economics, 86, 181-200. http://dx.doi.org/10.1016/j.jdeveco.2007.11.006

[33] La Porta, R., Lopez-de-Silanes, F., Shleifer, A. and Vishny, R. (1997) The Legal Determinants of External Finance. Journal of Finance, 52, 1131-1150. http://dx.doi.org/10.1111/j.1540-6261.1997.tb02727.x

[34] La Porta, R., Lopez-de-Silanes, F., Shleifer, A. and Vishny, R. (1998) Law and Finance. Journal of Political Economy, 106, 1113-1155. http://dx.doi.org/10.1086/250042

[35] La Porta, R., Lopez-de-Silanes, F., Shleifer, A. and Vishny, R. (1999) The Quality of Government. Journal of Law, Economics, and Organization, 15, 222-279. http://dx.doi.org/10.1093/jleo/15.1.222

[36] Pesaran, M.H., Shin, Y. and Smith, R.J. (2001) Bounds Testing Approaches to the Analysis of Level Relationships. Journal of Applied Econometrics, 16, 289-326. http://dx.doi.org/10.1002/jae.616

[37] World Bank (2012) World Development Indicators 2012. World Bank, Washington DC.

[38] Levine, R., Loayza, N. and Beck, T. (2000) Financial Intermediation and Growth: Causality and Causes. Journal of Monetary Economics, 46, 31-77. http://dx.doi.org/10.1016/S0304-3932(00)00017-9

[39] Chakraborty, I. (2010) Financial Development and Economic Growth in India: An Analysis of the Post-Reform Period. South Asia Economic Journal, 11, 287-308. http://dx.doi.org/10.1177/139156141001100206

[40] Shen, C.-H. and Lee, C.-C. (2006) Same Financial Development yet Different Economic Growth-Why? Journal of Money, Credit and Banking, 38, 1907-1944. http://dx.doi.org/10.1353/mcb.2006.0095 
[41] Yu, J.-S., Hassan, M.K. and Sanchez, B. (2012) A Re-Examination of Financial Development, Stock Markets Development and Economic Growth. Applied Economics, 44, 3479-3489. http://dx.doi.org/10.1080/00036846.2011.577019

[42] Manning, M.J. (2003) Finance Causes Growth: Can We Be So Sure? The B.E. Journal of Macroeconomics, 3, 1-24. http://dx.doi.org/10.2202/1534-6005.1100

[43] Tang, D. (2006) The Effect of Financial Development on Economic Growth: Evidence from the APEC Countries, 1981-2000. Applied Economics, 38, 1889-1904. http://dx.doi.org/10.1080/00036840500427239

[44] Shen, C.-H., Lee, C.-C., Chen, S.-W. and Xie, Z. (2011) Roles Played by Financial Development in Economic Growth: Application of the Flexible Regression Model. Empirical Economics, 41, 103-125. http://dx.doi.org/10.1007/s00181-010-0353-z

[45] Beck, T. and Levine, R. (2004) Stock Markets, Banks, and Growth: Panel Evidence. Journal of Banking and Finance, 28, 423-442. http://dx.doi.org/10.1016/S0378-4266(02)00408-9

[46] Yay, G. and Oktayer, A. (2009) Financial Development and Economic Growth—A Comparative Analysis. Romanian Journal of Economic Forecasting, 11, 56-74.

[47] Liu, W.-C. and Hsu, C.-M. (2006) The Role of Financial Development in Economic Growth: The Experiences of Taiwan, Korea, and Japan. Journal of Asian Economics, 17, 667-690. http://dx.doi.org/10.1016/j.asieco.2006.06.007

[48] Levine, R. and Demirguc-Kunt, A. (1996) Stock Market Development and Financial Intermediaries: Stylized Facts. World Bank Economic Review, 10, 291-321. http://dx.doi.org/10.1093/wber/10.2.291 